\title{
NEMEDIKAMENTINIAI IR MEDIKAMENTINIAI GIMDYMO SKAUSMO MALŠINIMO BŪDAI: GIMDYVIŲ TURIMOS IR GAUNAMOS ŽINIOS BEI PASIRINKIMAS
}

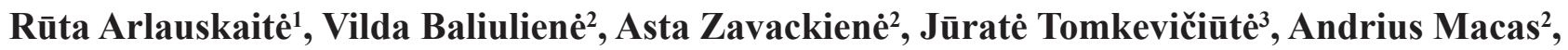 \\ Kęstutis Rimaitis ${ }^{2}$ \\ ${ }^{1}$ Lietuvos sveikatos mokslu universiteto Akušerijos-ginekologijos klinika, \\ ${ }^{2}$ Lietuvos sveikatos mokslu universiteto Anesteziologijos klinika, \\ ${ }^{3}$ Lietuvos sveikatos mokslu universiteto Medicinos akademija
}

Raktažodžiai: gimdymo skausmas, medikamentiniai ir nemedikamentiniai gimdymo skausmo malšinimo būdai.

\begin{abstract}
Santrauka
Tyrimo tikslas. Ivvertinti něščiujų turimas ir gaunamas žinias apie gimdymo skausmo malšinimo būdus. Tyrimo metodika. 2015 08-09 universitetinèje ligonineje atliktas retrospektyvinis tyrimas. Visoms gimdyvems po gimdymo išdalintos anketos. Rezultatai. Išdalinta 110 anketų. Atsako dažnis 94,5 proc. Pacienčių žinios apie galimus gimdymo skausmo malšinimo būdus buvo pakankamos. Atitinkamai žinomiausi nemedikamentinio ir medikamentinio gimdymo skausmo malšinimo būdai yra kvèpavimo pratimai ir epidurinè analgezija. Trūksta informacijos apie gimdymo analgezijos privalumus ir trūkumus. Panašus gimdyvių skaičius rinkosi medikamentinius ir nemedikamentinius metodus. Išvados. Dauguma gimdyvių žinojo apie epidurinę gimdymo analgeziją, tačiau buvo girdèję tik kelis natūralius gimdymo skausmo malšinimo būdus. Tikslinga moterims nèštumo metu suteikti daugiau informacijos apie gimdymo skausmo malšinimo būdus.
\end{abstract}

\section{İvadas}

Vienas iš labiausiai gąsdinančių, su něštumu susijusių veiksnių yra gimdymo skausmas [1]. Daugelis moterų gimdymo skausmą įvardija kaip patị stipriausią, kokị teko patirti gyvenime [2-4]. Gimdymo skausmo intensyvumą ir moters reakciją i ji lemia individualios gimdyvès savybès (psichoemocinis pasiruošimas gimdyti, socialinè ir kultūriné aplinka) ir gimdymo eigos ypatumai [4, 5]. Gimdymo metu iki 10 proc. moterų skausmo beveik nejaučia arba jis yra nestiprus, 40 proc. gimdyvių jaučia vidutinio stiprumo skausmus, apie 35 proc. - stiprius gimdymo skausmus ir apie 15 proc. - labai stiprius, nepakeliamus skausmus. Jei jaučiamas labai stiprus skausmas, dažniausiai tai susiję su nenormalia vaisiaus padètimi, gimdymo skatinamu vaistais ir didesniu medikamentinio skausmo malšinimo poreikiu [6]. PSO ir Amerikos Akušerijos ir Ginekologijos draugija teigia, kad gimdymo skausmas turi būti malšinamas sisteminiais skausmą malšinančiais medikamentais arba taikant regioninę analgeziją $[7,8]$. Tačiau kyla klausimas, ar visada reikia skausmą malšinti, nes skausmo patirtis nèra ilgalaikè ir 90 procentu moteru per 3 mènesius po gimdymo savo patirtą skausmą vertino tik kaip nestiprų [9].

Skausmas gali būti malšinamas medikamentiniais ir natūraliaisiais - nemedikamentiniais būdais [10,11]. Taikant medikamentines priemones tikslas yra skausmą sumažinti, nemedikamentines - sudaryti galimybes moteriai susitaikyti su esamu skausmu [12].

Rekomenduojama, kad pasirinktas gimdymo skausmo malšinimo būdas būtų individualus ir pritaikytas prie kiekvienos moters norų, poreikių ir aplinkybių [12]. Gimdant daug moteru, įskaitant tas, kurios tikejjosi gimdyti nenaudodamos medikamentinių metodų, suvokia, kad jos nepakankamai ịvertino ir tikèjosi mažesnio skausmo [13]. Nepaisant geresnio skausmo malšinimo ir nuosekliai mažejjančio gimdyvių ir naujagimių mirtingumo yra akivaizdus moters baimès ir nerimo dèl gimdymo didejjimas [14]. Nepakankamos žinios apie skirtingų gimdymo skausmo malšinimo metodų privalumus ir trūkumus gali dar labiau padidinti gimdyvès nerimą [15].

Nors informacija apie gimdymo skausmo malšinimo būdus, jų privalumus ir trūkumus yra lengvai prieinama, tačiau daugumai nėščiujų, net ir prasidèjus gimdymui, 
trūksta žinių apie tai ir dažnai jos nėra apsisprendusios, kuri skausmo malšinimo būdą pasirinkti [16].

Patikimas informacijos apie gimdymo skausmo malšinimą šaltinis gimdyvei yra akušerè. Deja, nėččiosioms lankantis moteru konsultacijoje, informacijos apie gimdymo skausmo malšinimo būdus ir jų poveikị suteikiama nepakankamai arba visai nesuteikiama. Sveikatos priežiūros darbuotojai, prižiūrintys ir mokantys moteris néštumo metu, turètų užtikrinti, kad nėščioji būtų tinkamai pasiruošusi gimdymui, kad lūkesčiai atitiktų realią patirtį bei didesni pasitenkinimą gimdymu [17].

Tyrimo tikslas - ịvertinti něščiųjų turimas ir gaunamas žinias apie gimdymo skausmo malšinimo būdus.

\section{Tyrimo metodika}

Noredami įvertinti gimdymo metu něšciujų turimas ir gaunamas žinias apie skausmo malšinimo būdus, pasirinkome trečio lygio paslaugas teikiantị stacionarą. Tyrimui atlikti gautas Etikos komiteto leidimas Nr. BEC - KK - 02 . Lietuvos sveikatos mokslų universiteto ligoninès Kauno klinikų Akušerijos skyriuje 2015 metų rugpjūčio-rugsèjo ménesiais atlikta anketinè apklausa. Apklaustos jau pagimdžiusios moterys.

Siekiant patikrinti, ar visi anketos klausimai yra aiškūs ir suprantami pradžioje atliktas bandomasis tyrimas,

1 lentelè. Moterų socialinė demografinè charakteristika *Kita: aukštesnysis, vidurinis, nebaigtas vidurinis.

\begin{tabular}{|c|c|c|c|c|c|c|}
\hline & \multicolumn{2}{|c|}{$\begin{array}{c}\text { Natūralieji } \\
\text { skausmo } \\
\text { malšinimo } \\
\text { būdai } \\
\text { n=47 (45,2 } \\
\text { proc.) }\end{array}$} & \multicolumn{2}{|c|}{$\begin{array}{c}\text { Medika- } \\
\text { mentiniai } \\
\text { skausmo } \\
\text { malšinimo } \\
\text { būdai } \\
\text { n=57 (54,8 } \\
\text { proc.) }\end{array}$} & & \\
\hline & $\mathrm{n}$ & $\%$ & $\mathrm{n}$ & $\%$ & $x^{2}$ & $\mathrm{p}$ \\
\hline $\begin{array}{l}\text { Amžiaus grupés } \\
\text { Iki } 30 \text { m. imtinai } \\
31 \mathrm{~m} . \text { ir daugiau }\end{array}$ & $\begin{array}{l}26 \\
21 \\
\end{array}$ & $\begin{array}{l}44,8 \\
45,7 \\
\end{array}$ & $\begin{array}{l}32 \\
25 \\
\end{array}$ & $\begin{array}{l}55,2 \\
54,3 \\
\end{array}$ & 0,007 & 0,933 \\
\hline $\begin{array}{l}\text { Šeimine padètis } \\
\text { Ištekèjusi ar gyve- } \\
\text { na nesusituokusi } \\
\text { Kita }\end{array}$ & $\begin{array}{l}44 \\
3\end{array}$ & $\begin{array}{l}44,4 \\
60,0\end{array}$ & $\begin{array}{l}55 \\
2\end{array}$ & $\begin{array}{l}55,6 \\
40,0\end{array}$ & 0,465 & 0,495 \\
\hline $\begin{array}{l}\text { Gyvenamoji vieta } \\
\text { Miestas } \\
\text { Kaimas }\end{array}$ & $\begin{array}{c}39 \\
8\end{array}$ & $\begin{array}{l}44,8 \\
47,1\end{array}$ & $\begin{array}{c}48 \\
9\end{array}$ & $\begin{array}{l}55,2 \\
52,9\end{array}$ & 0,029 & 0,866 \\
\hline $\begin{array}{l}\text { Išsilavinimas } \\
\text { Aukštasis } \\
\text { Kita* }\end{array}$ & $\begin{array}{l}32 \\
15\end{array}$ & $\begin{array}{l}44,4 \\
46,9\end{array}$ & $\begin{array}{l}40 \\
17\end{array}$ & $\begin{array}{l}55,6 \\
53,1\end{array}$ & 0,053 & 0,818 \\
\hline
\end{tabular}

išdalinta dešimt anketų. Prieš atliekant asmeninę anketinę apklausą, respondentèms paaiškintas tyrimo pobūdis ir tikslas. Supažindinus su tyrimo aspektais, duota pasirašyti "Informuoto sutikimo" forma. Apklaustos visos tyrime sutikusios dalyvauti gimdyvès, kurios tyrimo laikotarpiu gulejo Akušerijos skyriuje. Anketa paduota kiekvienai respondentei asmeniškai. Iš viso išdalinta 110 anketų, grąžintos 104 (atsako dažnis - 94,5 proc.).

Anketos klausimynas sudarytas iš trijų dalių: 1) socialiniai demografiniai duomenys; 2) klausimai, atspindintys turimas žinias apie gimdymo skausmo malšinimo būdus; 3 ) klausimai, atspindintys gaunamas žinias apie natūralius ir medikamentinius skausmo malšinimo būdus, jų trūkumus ir privalumus. Atsakymų variantai, atspindintys suteiktas žinias apie skausmo malšinimo metodų privalumus ir trūkumus, dar buvo suskirstyti ị tris grupes: 1. Taip (buvo pakankamai suteikta informacijos) 2. Ne (nebuvo kalbama, nesuteikta informacijos) 3. Nepakankamai (suteiktos informacijos kiekis nepakankamas). Siekiant išsiaiškinti turimas žinias ir jų šaltinį, buvo pateikti atsakymų variantai, galimybé pateikti savo variantą.

Statistinè duomenų analizė atlikta SPSS 17.0 programa. Nagrinėjamų kokybinių požymių reikšmių pasiskirstymai pasirinktoje imtyje įvertinti aprašomaja duomenų statistika - absoliučiaisiais (n) ir procentiniais dažniais (proc.). Kiekybiniai požymiai aprašyti aritmetiniu vidurkiu ir standartiniu nuokrypiu. Kokybinių požymių ryšiams vertinti sudarytos susijusių požymių lentelès, požymių priklausomybei (arba lyginamų grupių homogeniškumui) nustatyti skaičiuotas chi-kvadrato $\left(\chi^{2}\right)$ kriterijus. Kai statistinis reikšmingumo lygmuo $\mathrm{p}<0,05$, požymių sąsaja laikyta statistiškai

2 lentelè. Informacija, kurią nèštumo metu gimdyvėms suteikia akušerès

*Statistiškai reikšmingai dažniau informacija apie natūraliuju ir medikamentiniu gimdymo skausmo malšinimo metodus, ju privalumus bei trūkumus nesuteikiama arba suteikiama nepakankamai.

\begin{tabular}{|l|c|c|c|}
\hline & $\begin{array}{c}\text { Galimi gim- } \\
\text { dymo skaus- } \\
\text { mo malšini- } \\
\text { mo metodai }\end{array}$ & $\begin{array}{c}|c| \\
\text { Gimdymo skausmo malši- } \\
\text { nimo metodų privalumai ir } \\
\text { trūkumai }\end{array}$ \\
\hline & $\begin{array}{c}\text { Natūralieji, } \\
\text { nemedikamen- } \\
\text { tiniai }\end{array}$ & $\begin{array}{c}\text { Medikamen- } \\
\text { tiniai }\end{array}$ \\
\hline $\begin{array}{l}\text { Pakankamai } \\
\text { informacijos }\end{array}$ & $36.5 \%(\mathrm{n}=38)$ & $22,1 \%(\mathrm{n}=23)$ & $\begin{array}{c}33,7 \% \\
(\mathrm{n}=35)\end{array}$ \\
\hline $\begin{array}{l}\text { Dalinai infor- } \\
\text { muotos }\end{array}$ & $20,2 \%(\mathrm{n}=21)$ & $24,0 \%(\mathrm{n}=25)$ & $\begin{array}{c}57,7 \% \\
(\mathrm{n}=60)\end{array}$ \\
\hline $\begin{array}{l}\text { Nesuteikta } \\
\text { informacija }\end{array}$ & $43,3 \%(\mathrm{n}=45)$ & $53,8 \%(\mathrm{n}=56)$ & $\begin{array}{c}8,7 \% \\
(\mathrm{n}=9) .\end{array}$ \\
\hline$\chi^{2}$ & 8,788 & 19,750 & 37,519 \\
\hline $\mathrm{p}$ reikšmé & $0,012^{*}$ & $<0,001^{*}$ & $<0,001 *$ \\
\hline
\end{tabular}


reikšminga (arba lyginamų grupių nagrinejjamo kokybinio požymio reikšmių proporcijos reikšmingai skiriasi).

\section{Tyrimo rezultatai}

Tyrime dalyvavo 104 LSMUL KK Akušerijos skyriaus pacientès, kurios gimdymo metu rinkosi įvairius gimdymo skausmo malšinimo būdus. Gimdyvių vidutinis amžius - $30 \mathrm{~m}$. (standartinis nuokrypis $-4,88$ ), jauniausiai - 17 metų, vyriausiai - 47 metai. Tyrime dalyvavusių gimdyvių socialinè demografinè charakteristika pateikiama 1-oje lentelèje. Moterų, pasirinkusių nemedikamentinius arba medikamentinius gimdymo skausmo malšinimo metodus, proporcijos atskirose socialinių demografinių rodiklių grupèse statistiškai reikšmingai nesiskyrè.

44,8 proc. $(\mathrm{n}=26)$ gimdyvių iki $30 \mathrm{~m}$. imtinai rinkosi natūraliuosius gimdymo skausmo malšinimo būdus, 55,2 proc. $(\mathrm{n}=32)$ - medikamentinius; 45,7 proc. $(\mathrm{n}=21)$ vyresnių nei $30 \mathrm{~m}$. pacienčių rinkosi natūraliuosius būdus, medikamentinius $-54,3$ proc. $(\mathrm{n}=25)$; proporcijų skirtumas tarp amžiaus grupių statistiškai nereikšmingas $\left(\chi^{2}=0,007\right.$; $\mathrm{p}=0,933)$. Neturinčios aukštojo išsilavinimo gimdyvės kiek dažniau rinkosi natūraliuosius skausmo malšinimo metodus $-46,9$ proc. ( $\mathrm{n}=15)$, o turinčios aukštajị išsilavinimą (aukštasis universitetinis, aukštasis neuniversitetinis) labiau buvo linkusios pasirinkti medikamentinius skausmo malšinimo būdus $-55,6$ proc. $(n=40)$, tačiau skirtumas statistiškai nereikšmingas $\left(\chi^{2}=0,053 ; p=0,818\right)$.

Antroje lenteleje pateikti duomenys apie informaciją, kurią gauna néščiosios moterų konsultacijoje. Suteiktos informacijos ir nuomonès įtaka gimdyviu pasirinkimui pavaizduota 1-oje ir 2-oje diagramose.

Tyrimo duomenų analizè parodè, kad 73,1 proc. tiria-

1 diagrama. Akušerių suteiktos informacijos įtaka renkantis skausmo malšinimo būdą

*Akušerès suteikta informacija statistiškai reikšmingai neịtakojo moteru pasirinkimo

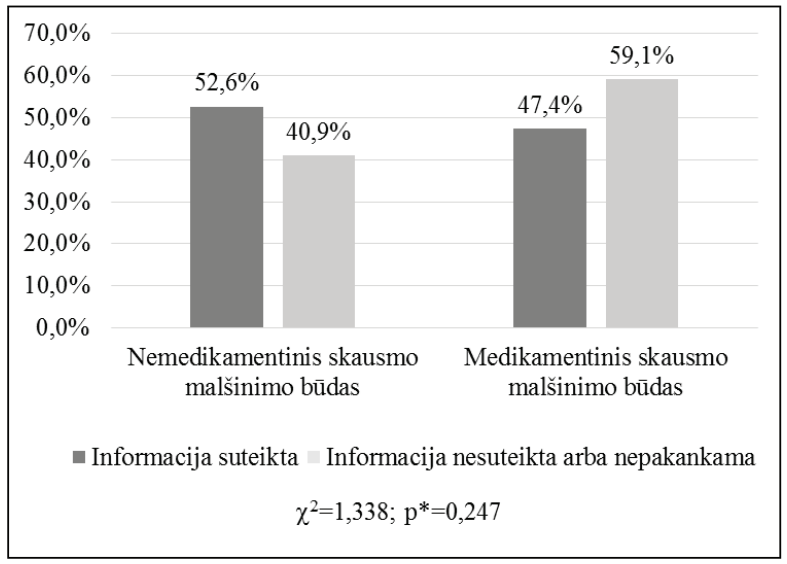

mujų ( $\mathrm{n}=76)$ nèštumo metu žinojo, kokie skausmo malšinimo metodai taikomi gimdymo metu, 15,4 proc. $(n=16)$ savo žinias i̇vertinimo kaip nepakankamas, o 11,5 proc. $(\mathrm{n}=12)$ visai nieko nežinojo, tačiau skirtumas lyginant nemedikamentinị ir medikamentinį skausmo malšinimo būdą pasirinkusias statistiškai nereikšmingas $\left(\chi^{2}=2,788\right.$, $\mathrm{p}=0,248$ ).

Vertintos gimdyvių žinios apie natūraliuosius skausmo malšinimo būdus. Nustatyta, kad labiausiai žinomi nemedikamentiniai gimdymo skausmo malšinimo būdai yra: kvèpavimo pratimai - žinojo 89,4 proc. $(n=93)$ tiriamujų, fizinis aktyvumas $-72,1$ proc. $(\mathrm{n}=75)$, masažas $-68,3$ proc. $(\mathrm{n}=71)$, hidroterapija $-28,8$ proc. $(\mathrm{n}=30)$, akupunktūra 11,5 proc. $(\mathrm{n}=12)$, akupresūra $-10,6$ proc. $(\mathrm{n}=11)$, karščio ir šalčio paketèliai $-8,7$ proc. $(n=9)$.

Vertinant, kokius medikamentinius gimdymo skausmo malšinimo būdus žino gimdyvès, paaiškèjo, kad epidurinę analgeziją žino 90,4 proc. (n=94) apklaustujų, taip pat 80,8 proc. ( $\mathrm{n}=84)$ gimdyvių mano, kad jis veiksmingiausias. Mažiau pacienčių žinojo apie „linksminančiąsias dujas“" - 49,0 proc. $(\mathrm{n}=51)$ ir spinalinę analgeziją - 42,3 proc. $(\mathrm{n}=44)$.

Iš tų gimdyvių, kurios iš anksto buvo apsisprendusios, kokị skausmo malšinimo būdą naudos (o tokių buvo 60,3 proc. ( $\mathrm{n}=63)$, nemedikamentinị skausmo malšinimo būdą pasirinko 44,4 proc. $(n=28)$, o medikamentini $-55,6$ proc. $(\mathrm{n}=35)$ gimdyviu $\left(\chi^{2}=0,378 ; \mathrm{p}=0,778\right)$. Apklausos duomenimis, 54,8 proc. $(\mathrm{n}=57)$ gimdyviu gimdymo metu pasirinko medikamentinị skausmo malšinimo būdą, 45,2 proc. $(\mathrm{n}=47)$ - natūraluji $\left(\chi^{2}=0,327 ; \mathrm{p}=0,962\right)$. Kito gimdymo metu 95,2 proc. $(\mathrm{n}=99)$ pacienčių pasirinktų tą patị skausmo malšinimo būdą. Nustatyta, kad 73,9 proc. $(\mathrm{n}=17)$ gim-

2 diagrama. Akušerès nuomonès itaka renkantis skausmo malšinimo būdą

*Akušerès nuomoné statistiškai reikšmingai neịtakojo moteru pasirinkimo

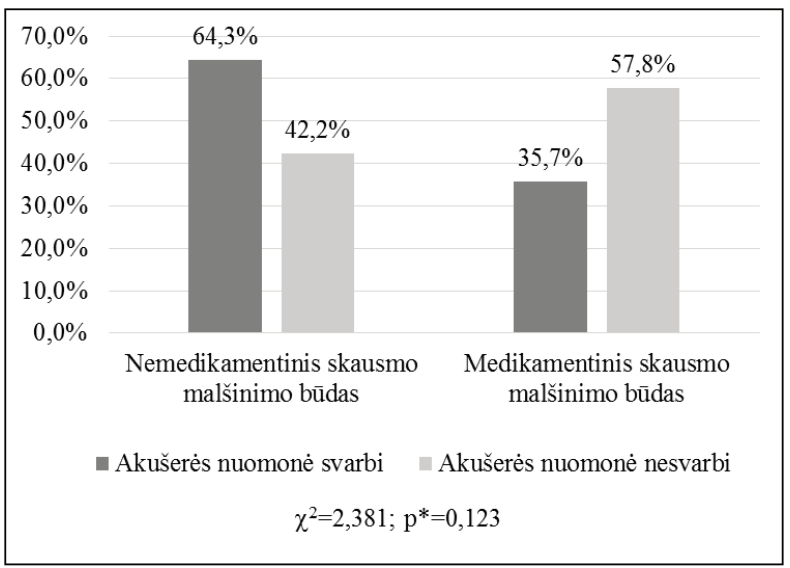


dyvių, kurioms nėštumo metu buvo paaiškinti nemedikamentinių skausmo malšinimo būdų privalumai ir trūkumai, gimdymo metu pasirinko natūralųi skausmo malšinimo būdą. Iš tų, kurioms buvo tik iš dalies paaiškinta ar išvis nepaaiškinta, natūralujji skausmo malšinimo būdą rinkosi tik 37,0 proc. $(n=30)$ gimdyviu $\left(\chi^{2}=9,835 ; p=0,002\right)$. Taikyto gimdymo skausmo malšinimo metodo indikacijos: gimdyvių pageidavimas 68,3 proc., medicininès indikacijos 16,3 proc., gydytoju rekomendacijos 15,4 proc. Vertintos ir gimdyvių pasirinkimą lemiančios priežastys: skausmo baimé 54,8 proc. $(\mathrm{n}=57)$, baimè pakenkti vaikeliui 53,8 proc. $(\mathrm{n}=56)$, noras aktyviai dalyvauti gimdymo procese 48,1 proc. $(\mathrm{n}=50)$, medicininès indikacijos 40,4 proc. $(\mathrm{n}=42)$, akušerès patarimas 16,3 proc. $(n=17)$, statistiškai reikšmingo skirtumo nèra ( $\mathrm{p}>$ visoms priežastims).

\section{Rezultatų aptarimas}

Remiantis LSMUL KK Anesteziologijos klinikos metiniais duomenimis, 2014 metais LSMUL KK Akušerijosginekologijos klinikoje ịvyko 2321 gimdymai natūraliais takais. Epiduriné analgezija buvo atlikta 871 (37,5proc), spinaliné analgezija $-9(0,4$ proc.), o sisteminè analgezija: kaukinè -437 (18,8 proc.), intraveninè - 6 (0,3proc.). Medikamentiniai skausmo malšinimo būdai nebuvo taikomi 998 (43,0proc.) gimdymų metu.

Koteles J. ir kolegų (2008) atliktoje apklausoje nustatyta, kad epidurinè analgezija Kanadoje dažniau atliekama pirmakartẻms, turinčioms aukštesni išsilavinimą bei didesnes pajamas gimdyvėms, o pasitenkinimas gimdymu buvo didelis nepaisant naudoto skausmo malšinimo būdo, kadangi skausmas gimdymo metu yra tik viena nedidelè viso proceso dalis [17]. Tačiau kanadiečių bei mūsų tyrimo duomenys nepatvirtina ankstesnių literatūroje pateikiamų rezultatų, susiejančių amžių su didesniu epidurinès analgezijos dažniu. Taipogi tikètina, kad labiau išsilavinusios, turinčios didesnes pajamas ir dirbančios pilną darbo dieną moterys, siekdamos kontroliuoti gimdymo skausmą, dažniau pageidaus epidurinès analgezijos, tačiau mūsų tyrimo duomenimis, išsilavinimo lemiamas skirtumas labai nežymus, tikriausiai dèl to, kad išsilavinusios moterys daugiau domisi ir galimu šalutiniu poveikiu bei esamais natūraliaisiais analgezijos metodais. Nustatyta, kad 73,9 proc. ( $\mathrm{n}=$ 17) gimdyvių, kurioms néštumo metu buvo paaiškinta apie nemedikamentinių skausmo malšinimo būdų privalumus ir trūkumus, gimdymo metu pasirinko natūralujị skausmo malšinimo būdą.

Něščiosioms suteikus informaciją, jos igyja platesnes galimybes rinktis, kokị skausmo malšinimo būdą norètų naudoti gimdymo metu. Nors numatyti, koks bus skausmo intensyvumas, labai sunku, tačiau planavimas turi privalu- mų. Nėščioji, kuri iki gimdymo išsiaiškina/arba supažindinta su skausmo malšinimo būdais, jų privalumais ir trūkumais, lengviau gali priimti tinkamiausią sprendimą. Gibson E. su kolegomis (2014) Floridoje atliko tyrimą, kuriame siekè išsiaiškinti moterų požiūrị ị skausmo malšinimo būdų pasirinkimą ir pasirinkimo priežastis [18]. Tyrimas parodè, kad natūraliuosius metodus pasirinko - 50,0 proc., medikamentinius - 50,0 proc., pasirinkusios nemedikamentinius metodus savo pagrindine pasirinkimo priežastimi įvardijo gimdymo skausmą kaip natūralų dalyką [7]. Mūsų apklausos duomenimis, 54,8 proc. gimdyviu gimdymo metu pasirinko medikamentinị skausmo malšinimo būdą, 45,2 proc. - natūralujji, o dažniausia pasirinkimo priežastis - baimè pakenkti naujagimiui $(53,8$ proc.) ir skausmo baimè $(54,8$ proc.). Nabukenya M. ir kolegu (2015) atliktame tyrime gimdyvès, kaip ir mūsų tirtos moterys, labiausiai nerimavo dèl poveikio naujagimiui $(54,5$ proc.) ir kad metodas gali būti neveiksmingas (23,4 proc.) [13].

Be abejo, pasirenkant skausmo malšinimo būdą gimdymo metu, daug įtakos turi šalia gimdyvès esantys sveikatos priežiūros darbuotojai, kurie ja rūpinasi viso gimdymo metu ir jų nuomoné bei kvalifikacija dažnai lemia pasirenkamą analgezijos būdą, taip pat svarbu gimdyvès psichologinè būsena, turimos patirtys.

Pagrindiniai gaunamos informacijos šaltiniai svyruoja priklausomai nuo šalies. Anarado A. ir kolegų (2015) atliktame tyrime 46,0 proc. informaciją suteike sveikatos priežiūros darbuotojai, 26,8 proc. giminès ir draugai, 7,1 proc. žiniasklaida [12]. Nabukenya M. ir kolegų tyrimo duomenimis, akušerès visai nesuteikia tokios informacijos antenatalinių vizitų metu, o daugiausia informacija gaunama iš šeimos nariu 47 proc., iš ankstesnio gimdymo patirties 26 proc., žiniasklaidos 7 proc. [13]. Mūsų tirtoms moterims antenatalinių vizitų metu akušerès apie galimus skausmo malšinimo būdus suteikè pakankamai informacijos 36,5 proc., dar 20,2 proc. informacija buvo suteikta dalinai.

Gimdžiusių moterų, kurios teigia bent kartą naudojusios alternatyvius analgezijos metodus, procentas skirtingose šalyse svyruoja labai žymiai: Afrikoje 80 proc., Kanadoje 70 proc., Prancūzijoje 49 proc., Australijoje 46 proc., Jungtinèse Valstijose 42 proc., Kinijoje 40 proc., Belgijoje 31 proc. ir Olandijoje 18 proc. [14].

Anarado A. su kolegomis (2015) Nigerijoje atliko tyrimą, kuriame vertino gimdyvių žinias apie nemedikamentinius gimdymo analgezijos metodus. Didžioji dalis, 80,8 proc., respondenčių žinojo, kad gimdymo skausmą galima kontroliuoti. Tai, kad gimdymo skausmui malšinti naudojami nemedikamentiniai metodai žinojo 68,6 proc. Daugiausia moteru žinojo apie kvèpavimo pratimus $(51,8$ proc.), masažą (36,7 proc.), fizini aktyvumą (32,2 proc.), 
relaksaciją (26,5 proc.). Tik 21,2 proc. galejjo įvardinti po 2 nemedikamentinio skausmo malšinimo privalumus ir trūkumus [12]. Mūsų tyrimo duomenimis, 73,1 proc. žinojo apie galimus skausmo malšinimo metodus. Žinomiausi nemedikamentiniai gimdymo skausmo malšinimo būdai yra panašūs: kvejpavimo pratimai $(89,4$ proc.), fizinis aktyvumas ( 72,1 proc.), masažas (68,3 proc.). Net 53,8 proc. mūsų tirtų moterų teigia, kad nebuvo suteikta informacijos apie šių metodų privalumus ir trūkumus. Tendencija tokia, kad dauguma moterų žino apie nemedikamentinę analgeziją, tačiau tos žinios labai paviršutiniškos.

Shorofi (2010) teigia, kad 40 proc. akušerių nèra pakankamai apmokytos suteikti informaciją apie skausmo malšinimo būdus [19].

Siekiant paskatinti nemedikamentinių metodų naudojimą bei užtikrinti efektyvumą ir saugumą svarbu, kad didètų taikančių alternatyvius gimdymo skausmo malšinimo būdus akušerių skaičius. Nemedikamentinès analgezijos ištekliai akredituotose, užtikrinančiose normalią gimdymo priežiūrą, ligoninèse turètų būti standartizuoti. Nacionalinejje slaugos ir medicininio mokymo konferencijoje (National Conference on Nursing and Medical Education) rekomenduota ị sveikatos priežiūros profesionalų studijas ịtraukti nemedikamentinių skausmo malšinimo būdų mokymą. $2002 \mathrm{~m}$. Tarptautinè akušeriu sajunga (the International Confederation of Midwives) išspausdino gaires apie bazines akušerių žinias, igūdžius ir elgesị, kurie būtini mažinat riziką klinikinejje praktikoje. Kompetencija Nr.4 apima komforto priemones gimdant, tokias kaip emocinis palaikymas ir nemedikamentiniai skausmo malšinimo metodai. Svarbiausia idejja yra, kad besilaukiančios mamos galètų rinktis iš įvairių diskomfortą ir skausmą gimdymo metu palengvinančių priemonių. Munoz-Selles ir kolegų (2013) atlikto tyrimo rezultatai rodo, kad kai kurios akušerès yra apmokytos nemedikamentinių metodų, bet negali jų taikyti dèl specifinès įrangos trūkumo ar nepakankamų ligoninès resursų [1]. Lietuvoje akušerių studijų programoje nèra itraukti mokymai apie nemedikamentinius skausmo malšinimo būdus. Kad klinikinejje praktikoje būtų galima naudoti ir alternatyvius gimdymo skausmo malšinimo būdus, reikètų skirti daugiau resursų mokymui, infrastruktūrai ir ịrangai. Šiuo metu mokymai tiek Ispanijoje, tiek Lietuvoje priklauso nuo individualios iniciatyvos.

Gimdyvių žinios apie epidurinę analgeziją skiriasi priklausomai nuo šalies. Italijoje epidurinę analgeziją žino 47 proc. moteru, Portugalijoje 64 proc., o Didžiojoje Britanijoje, Suomijoje, Belgijoje 94-100 proc. Šie skirtumai tikriausiai daugiau ne mokymo, o požiūrio ì gimdymo skausmo malšinimą ir propaguojamų analgezijos metodų atspindys [16]. Nabukenya M. ir kolegos apklausè 1293 pagimdžiu- sias moteris, tik 7 proc. žinojo apie gimdymo analgeziją, bet suteikus informaciją, kito gimdymo metu 87,7 proc. pasirinktų medikamentinį skausmo malšinimo metodą. Informacija apie medikamentinius metodus šioje šalyje yra labai ribota, tačiau akušerès yra plačiau susipažinusios su natūraliais skausmo malšinimo būdais [13]. Wendy Ch. su kolegomis (2010) atlikto tyrimo, lyginusio gimdyves Belgijoje ir Olandijoje, išvada, kad Olandijoje moterys šešis kartus rečiau renkasi medikamentinius metodus skausmui malšinti [16]. Skiriasi žinių lygis skirtingose šalyse, skiriasi ir atliekamos epidurinès analgezijos dažnis: Belgijoje 66,6 proc., Olandijoje - 9,6 proc., Lenkijoje - 55 proc., Vokietijoje $-86,6$ proc., Norvegijoje $-29,5$ proc., Jungtineje Karalystejje $-29,4$ proc. [6, 20-23]. Tuo metu mūsų atlikto tyrimo duomenimis, net 90,4 proc. gimdyvių žino apie epidurinę analgeziją, taip pat 80,8 proc. gimdyvių mano, kad jis efektyviausias. Mūsų atliktos apklausos duomenimis, 54,8 proc. gimdyvių gimdymo metu pasirinko medikamentinį skausmo malšinimo būdą. Kito gimdymo metu 95,2 proc. pacienčių pasirinktų tą patị skausmo malšinimo būdą. Mūsų tyrime dažniau naudojami medikamentiniai metodai galbūt todèl, kad apklausėme trečio lygio stacionaro pacientes, čia didesnè patologinio gimdymo tikimybė, kuomet skausmas gali būti stipresnis (skatinimas, vaisiaus padètis) ar rekomenduojama atlikti epidurinę analgeziją (randas po cezario pjūvio operacijos, preeklampsija). Tačiau 66,4 proc. něščiujų mano, kad antenatalinès priežiūros metu akušerè suteikè nepakankamai informacijos apie medikamentinius skausmo malšinimo būdus, tai rodo, kad ir Lietuvoje akušerèms trūksta žinių apie šiuos metodus.

Hodenet E. D. (2002) atlikta sisteminé apžvalga nustatė, kad vertinant gimdymą, moteriai yra svarbiausi keturi kintamieji (asmeninè patirtis, sveikatos priežiūros darbuotojų parama, sveikatos priežiūros darbuotojų ir pacientès tarpusavio santykių kokybè, dalyvavimas priimant sprendimus). Šie veiksniai vertinant gimdymo patirti yra svarbesni nei ekonominè padètis, amžiaus įtaka, socialinè padètis, etniškumas, pasiruošimas gimdymui, gimdymo aplinka, skausmas, nejudra, medicininès intervencijos ir pastovi priežiūra [14]. Mūsų tyrimo duomenimis, moterys, kurioms svarbi akušerés nuomoné, dažniau rinkosi natūraliuosius gimdymo skausmo malšinimo būdus (64,3 proc.), o jei nuomonè nesvarbi - teiké pirmenybę medikamentiniams būdams (57,8 proc.).

\section{Išvados}

Daugumai gimdyvių nèra suteikiama išsami informacija apie gimdymo skausmo malšinimo būdų privalumus ir trūkumus. Kiek daugiau nei trečdalis gimdyvių gauna pakankamai informacijos apie medikamentinių skausmo 
malšinimo būdų privalumus ir trūkumus.

Didesnè dalis gimdyvių yra supažindintos/susipažinusios tik su keliais natūraliaisiais skausmo malšinimo būdais. Labiausiai žinomi - kvėpavimo pratimai, fizinis aktyvumas.

Dažniausi pasirenkamą gimdymo skausmo malšinimo būdą lemiantys veiksniai yra baimé pakenkti vaikeliui ir skausmo baimé, taip pat noras aktyviai dalyvauti gimdymo procese.

Akušerès nuomonė yra svarbi renkantis gimdymo analgeziją. Kadangi akušerès suteikiama informacija ir kompetencija yra reikšminga gimdyvėms, siekiant supažindinti su nemedikamentine gimdymo analgezija rekomenduojama papildyti akušerių studijų programą.

\section{Literatūra}

1. Ester Mu-oz-Sellés, Antoni Vallès-Segalés and Josefina Goberna-Tricas Use of alternative and complementary therapies in labor and delivery care: a cross-sectional. study of midwives' training in Catalan hospitals accredited as centers for normal birth BMC Complementary and Alternative Medicine 2013; 13:318. http://www.biomedcentral.com/1472-6882/13/318 http://dx.doi.org/10.1186/1472-6882-13-318

2. Kiškūnè J., Pociūtè R. Gimdymas ir gimimas: šiandieninès patirtys pribuvėjystės istorijos kontekste. Vilnius, 2005; 136142.

3. Nadišauskienė R. Gimdymas. Gimdymo skausmo malšinimas. Kaunas, 2010; p. 36-42.

4. Niven CA, Murphy - Black T. Memory for labor pain: a review of the literature. Birth, 2000 Dec; 27(4): 244-53.

http://dx.doi.org/10.1046/j.1523-536x.2000.00244.x

5. Marchertienė I., Dulevičius Z. Ūminis skausmas ir jo malšinimas. Kaunas, 2001; 144.

6. Leap N. Working with pain in labour. New Digest 49. 2010 January.

7. WHO Normative Guidelines on Pain Management, Geneva, June 2007, Available from: http://www.who.int/medicines/ areas/quality_safety/delphi_study_pain_guidelines.pdf.

8. Hodnett E, Gates S, Hofmeyr G. et al: Continuous support for women during childbirth, Cochrane Database Syst Rev 2011; 3 CD003766.

http://dx.doi.org/10.1002/14651858.cd003766.pub3

9. Rimaitis K, Kačiurinienè V., Macas A. The influence of postpartum mood disorders on parturient satisfaction with labour analgesia NWAC - Nysora World Anesthesia Congress: Poster. Abstracts: Dubai, 7th-12th March 2010 / Scientific Chairmain: A. Hadzic. Dubai

10. Internetinė prieiga: http://www.psych.usyd.edu.au/cemped/ docs/Pain_Decision_Aid.pdf.

11. Halpern SH, Restrepo MS. Effects on fetus of systemic vs. neuraxial analgesia. In: Ginostar Y, Reynolds F, editors. Anesthesia and the Fetus. Oxford: Wiley - Blackwell; 2013; 263-269.

http://dx.doi.org/10.1002/9781118477076.ch28

12. Anarado A, Ali E, Nwonu E. et al. Knowledge and willingness of prenatal women in Enugu Southeastern Nigeria to use in labour non-pharmacological pain reliefs. African Health Sciences 2015; 15(2):568-575.

http://dx.doi.org/10.4314/ahs.v15i2.32

13. Nabukenya MT, Kentu A, Wabules A, Muyingo MT, Kwizera A. Knowlegde, attitudes and use of labour analgesia among women at a low-income country antenatal clinic.BMC Anesthesiology 2015; 15:98.

http://dx.doi.org/10.1186/s12871-015-0078-9

14. Hodenett ED. Pain and women's satisfaction with the experience of childbirth: a systematic review. Am J Obstet Gynecol 2002; 186: S160-72.

15. Lally JE, Thomson RG., MacPhail Sh.and Exley C. Pain relief in labour: a qualitative study to determine how to support women to make decisions about pain relief in labour. BMC Pregnancy and Childbirth 2014,14:6 doi:10.1186/1471-239314-6.

http://dx.doi.org/10.1186/1471-2393-14-6

16. Wendy Ch, Mieke V, Bracke P. Pain acceptance and personal control in pain relief in two maternity care models: a cross-national comparison of Belgium and the Netherlands. Department of Sociology, Ghent University, Ghent, Belgium BMC Health Services Research 2007; 10.1186/1471-2393-7-26.

http://dx.doi.org/10.1186/1471-2393-7-26

17. Waldenstrom U, Schytt EA. Longitudinal study of women's memory of labour pain - from 2 months to 5 years after the birth. An International J of Ostetr and Gyn 2008; 577 - 583.

18. Gibson E. Women's expectations and experiences with labour pain in medical and midwifery models of birth in the United States Women Birth 2014 Sep; 27(3): 185-9.

19. Shorofi SA, Arbon P. Nurses, knowledge, attitudes and professional use of complementary and alternative medicine (CAM) a survey at five metropolitan hospitals in Adelaine. 2010.05.008. Epub 2010 Jun 11.

20. Griffiths ChR, Doering K, Patterson J. Japanese women's experiences of pharmacological pain relief in New Zealand, School of Midwifery, Te Kura atawhai ka Kaiakopono te Hakuitaka, Otago Polytechnic, Te Kura Matatini ki Otago, New Zealand Women and Birth (Impact Factor: 1.57).12/2013; 27(2). DOI: 10.1016/j.wombi.2013.11.005.

21. Stamer UM, Messerschmidt A, Wulf H, Hoeft A. Practice of epidural analgesia for labour pain: a German survey. Stamer UM1,Messerschmidt A,Wulf H,Hoeft A. Eur J Anaesthesiol 1999 May; 16(5):308-14. http://dx.doi.org/10.1097/00003643-199905000-00008

22. Tveit TO, Halvorsen A, Rosland JH. Analgesia for labour a survey of Norwegian practice - with focus on parental opioids. Article first published online: 14 may 2009. 10.4137/CMWH. S8015 
23. Callister LC, RN, FAAN, Getmanenko N, Garvrish N, Eugenevna, Marakova O. RN; Vladimirova, Zotina N. RN; Lassetter, Jane MSN, RN; Turkina, N. MD. Giving Birth: The Voices of Russian Women. MCN, The American Journal of Maternal/ Child Nursing February 2007; 18- 24.

\section{NONPHARMACOLOGICAL AND}

PHARMACOLOGICAL LABOUR ANALGESIA: KNOWLEDGE, ACQUIRED INFORMATION AND CHOICE OF PARTURIENT

R. Arlauskaitė, V. Baliulienė, A. Zavackienė, J. Tomkevičiūtė, A. Macas, K. Rimaitis

Key words: labour analgesia, pharmacological and nonpharmacological methods.

Summary

Aim of the study. To evaluate the knowledge and the information about labour analgesia that is provided for pregnant women.
Methods: A retrospective cohort study was carried in a teaching hospital during 2015 08-09. The questionnaires were given to all parturients after delivery. Results: 110 questionnaires were given, the response rate was $94.5 \%$. Knowledge of the parturients about possible methods of labour analgesia was sufficient. The most known natural and pharmacological labour analgesia methods were breathing exercises and epidural analgesia respectively. Information provided about advantages and disadvantages of labour analgesia is insufficient. The number of parturients who chose pharmacological and nonpharmacological methods was almost equal. Conclusions: Most of parturients knew about epidural labour analgesia, but they knew just a few natural methods. More information should be provided for women during pregnancy.

Correspondence to: arlauskaite.ruta@gmail.com

Gauta 2016-09-12

\section{KVIEČIAME PRENUMERUOTI “SVEIKATOS MOKSLŲ” ŽURNALĄ 2017 METAIS!}

Žurnalas "Sveikatos mokslai" (Index Copernicus, EBSCO host (Academic Search Complete), Gale (Academic OneFile), ProQuest (Ulrich's, Summon), Australia (ERA) 2012 Journal List (ERA ID 34962) skirtas visu specialybiu gydytojams, slaugytojams ir kitiems specialistams, spausdina mokslinius straipsnius lietuvių, anglų kalbomis. Reikalavimai straipsniams atitinka mokslo leidiniams keliamus reikalavimus.

Žurnalas kioskuose neparduodamas.

Žurnalą, kuris leidžiamas kartą per du mẻnesius, galima užsiprenumeruoti visuose Lietuvos pašto skyriuose, taip pat internetu: www.prenumeruok.lt

Prenumeratos kaina nesikeičia: visiems metams - 34,75 EUR, šešiems mẻnesiams - 17,37 EUR, keturiems mẻnesiams - 11,58 EUR, dviem mẻnesiams - 5,79 EUR.

Prenumeratos kodas: 5348.

Žurnalo autoriams straipsnių spausdinimas mokamas.

Redakcija 